\title{
ABCG Synergism to Stimulate One Health Collaboration: A Study on Mental Health and Psychosocial Support Program in West Lombok, West Nusa Tenggara
}

\author{
Ni Komang Semara Yanti ${ }^{1}$, Ni Nyoman Sri Budayanti ${ }^{1, *}$ \\ ${ }^{1}$ Udayana One Health Collaborating Center Universitas Udayana, Bali, Indonesia \\ ${ }^{*}$ Corresponding author. Email: nyomansribudayanti@gmail.com
}

\begin{abstract}
Cross-sector collaboration is one way that can be done to increase the potential of the organization, improve service effectiveness, and open opportunities for further collaboration in the future. As part of efforts to overcome mental health trauma among the earthquake survivors in Lombok, West Nusa Tenggara, Udayana One Health Collaborating Center (Udayana OHCC) launched an effort in 2019 to integrate the academic, business, community and government (ABCG) into the mental health and psychosocial support programs. The central theme was the process and the importance of the collaboration strategies among the parties. This study aims to observe the collaboration process between ABCG to deliver the program and elaborate on the role of each party in providing services to the community. This study also aims to build a basis for future research regarding ABCG collaboration in delivering community development projects. Our findings indicated that collaboration was best delivered when all parties involved had similar visions and considering other parties' needs and goals. In this case, academics and business ensure the implementation of the program, both ensuring quality and financial security. As the party that has the authority, the government plays an essential role in communicating the program to the community. Likewise, the community also plays a crucial role in the sustainability of the program. Challenges, such as miscommunication and the existence of special norms applicable in the local area can be overcome by the existence of a clear division of duties in the collaboration agreement between all parties. Realizing that there is no dominant party is also one of the important things to hold the community for the sake of program sustainability. Following the practice, it is recommended that program makers work together with the local community to develop and implement the program, as well as facilitating collaboration across agencies to maintain the quality and sustainability of the program.
\end{abstract}

Keywords: collaboration, $A B C G$, community development

\section{INTRODUCTION}

The importance of stakeholders and interdisciplinary collaboration have highlighted in the field of project management. The benefit of the project, in terms of individual and institutional, has explicitly described being something that should be openly known for anyone involved in it [1][2]. For most of the time, a failure in the project is were not caused by ineffective project management practices, but because of inappropriate or lacking social interactions among the parties involved [3].

Awareness of the effective management of socioecological systems has grown, as well as the awareness of the needs of collaboration on all levels. The project holder would not be able to run a holistic project when it is lack of participation from other parties such as policymakers, academic, private sectors, and of course the community.
In recent years, a range of analysis has been done to describe the role of stakeholder's collaboration in the project and present various outcomes based on the proportion of each party [4-6].

Cross-discipline collaboration has been assigned as an innovative action to bridge the agendas of stakeholders and the needs of community [7]. In the community development field, the emergence of this type of collaboration is a sign of a potential sustainable and effective program. It is also has been recognized to be able to address the governance deficit, implementation deficit, and participation deficit [8].

In this study, we are focusing on the academic, business, community and government (ABCG) analysis and engagement in Udayana OHCC's 'Mental Health and Psychosocial Support - NIVEA Sentuhan Ibu ${ }^{\mathrm{TM}}$ ' Project. This project started as a response to the current condition of the earthquake victims from July 2018's 7.0 SR earthquake. Theoretically, adverse effects that victims 
will feel when experiencing stress may reflect in the form of loss of concentration, reluctance to interact with the environment, insomnia or sleeping difficulty, feeling lonely and often having nightmares. If that condition is not handled correctly, it will harm the victims in the future, especially among mothers and children. Responding to the condition, the activity of Mental Health and Psychosocial Support was conducted by Udayana One Health Collaborating Center, Udayana University. The intervention consists of mindfulness and plays therapy that also puts forward interaction between mother and child, such as touching and storytelling.

Through this program, University can do the three values of higher education (community, research and education) and in line with the corporate social responsibility (CSR) of PT. Beiersdorf Indonesia (NIVEA Sentuhan $\mathrm{Ibu}^{\mathrm{TM}}$ ).

Besides, this program also takes collaboration with some stakeholders to implement the concept of Academician Business Government (ABG), including West Lombok District Board for Disaster Management, Government of Kekait Village, Mutiara Sukma Mental Hospital, Social Service Office, Primary Health Centre of Gunung Sari Sub-district, Psychologist Union in Mataram, University of Mataram, Mataram National Islamic University and Stikes Yarsi Mataram, as well as involving the mothers and children at the Kekait village, West Lombok.

This study aims to observe the collaboration process between $\mathrm{ABCG}$ to deliver the program and elaborate on the role of each party in providing services to the community. This study also aims to build a basis for future research regarding $\mathrm{ABCG}$ collaboration in delivering community development projects.

\section{METHOD}

We explore the formation and function of collaboration in delivering a social project in the field of mental health and community development. The research context is the classification of each actor's aims, role and responsibilities. Thus, we used a one case study observation (case approach) as this method is best used to explain a situation in which behavioral manipulation or control is neither feasible nor desirable [9]. Our collaboration concept matrix was constructed based on Missonier and Loufrani-Fedida [10] and Bitzer, Glasbergen [11].

\section{RESULTS AND DISCUSSION}

\section{Project Implementation}

The project implemented in three phases consists of preparation stage, intervention, and follow-up phase. The detail of these phases are as follows:

\section{Preparation Stage}

This stage started with a preliminary survey to see the general condition of Kekait village and establishing collaboration with West Lombok District Board for Disaster Management, Mutiara Sukma Mental Hospital of West Nusa Tenggara and the Government of Kekait Village. The survey was also done to see the current situation at transitional residence/Hunian Sementara (Huntara).

After we compile results from the preliminary survey, the team developed the Term of Reference and budgeting plan according to the condition that we observed in Kekait, with full support from the local government of Kekait. Besides planning the interventions (psychosocial support therapies) and follow up plan, we also planned additional activities such as Watching with Community/Open Air Cinema (Nonton Bareng) and Personal Hygiene and Disaster Preparedness Socialisation for students in collaboration with West Lombok District Board for Disaster Management, Primary Health Centre of Gunung Sari Sub-district and Stikes Yarsi Mataram.

The collaboration for this program involving three parts, namely the academic (OHCC Udayana University), Business (PT. Beiersdorf Indonesia), and Government (Coordinating Ministry for Human Development and Cultural Affairs). To ensure the collaboration between all parts, an agreement/MoU was made and checked by all parties. Team also developed two sets of questionnaire to assess the pre-intervention situation of the mothers and children and two intervention modules based on the result of the assessment.

\section{Intervention Stage}

We acknowledge the importance of involving the local cadres as a way to engage with the community. In Kekait, these cadres played a crucial part in gaining people's trust and helped in communicating with the locals using Bahasa Sasak. We involved Karang Taruna (youth organisation) and Kader Posyandu (Health assistant cadres), as well as involving local Pesantren (Pesantren At-Tahzib).

The intervention took place at Madrasah Aliyah and Madrasah Tsanawiyah ATTAZHIB, located close to the central transitional residence of Kekait Village and conducted three times with two weeks interval between the interventions. These sessions have been started from 22 June 2019 and ended on 21 July 2019.

For the intervention, we involved cadres and Karang Taruna to ensure the presence of the selected respondents to the therapy sessions. Therapists/Psychologists for this intervention were employed from Udayana University and various institutions in West Nusa Tenggara namely Mutiara Sukma Mental Hospital, Social Service Office and UIN Mataram under the coordination with Psychologist Union in Mataram/Himpunan Psikolog Mataram. We involved psychologists from Mataram to make sure the sustainability of the program, as they will be much easier to reach by the people of Kekait village after the program ended. Each therapist needs assistants to deliver the intervention. Thus, we established collaboration with Mataram University and Mataram National Islamic University, as their students may help the therapists in the process of therapy. Besides, these students can learn and apply their knowledge in the real situation, so that it helped them in gaining real-life experiences.

\section{Follow Up}


The follow-up activity was done as a post-intervention evaluation and incorporated with the village activities for Indonesian Independence day celebration on August 17th, 2019. A closing ceremony and post-test also were done to mark the closure of the activities.

\section{Stakeholder Relationships}

These steps summarise the role of each actor involved. At the beginning of this project, the actors' activity mostly leaned on a 'compromiser' role, as each part of the project attempted to discuss, negotiate and create an informed agreement among them. This finding is similar to Missonier and Loufrani-Fedida [10]'s findings regarding the beginning of a partnership. By the time, we also found that the roles were fluidly changed throughout the project. After the agreement signed between ABG partners, each actor realigned their goals and interests for the sustainability of mutual collaboration. The matrix of this collaboration is as follows.

Table 1. Matrix of Collaboration on Mental Health \& Psychosocial Support (Sentuhan Ibu ${ }^{\mathrm{TM}}$ ) Project

\begin{tabular}{|c|c|c|c|c|c|c|c|c|c|c|}
\hline \multirow[t]{2}{*}{ Features } & \multicolumn{10}{|l|}{ Group Actors } \\
\hline & $\begin{array}{l}\text { PT } \\
\text { Beiersdorf } \\
\text { (NIVEA) }\end{array}$ & $\begin{array}{l}\text { Udayana } \\
\text { OHCC }\end{array}$ & $\begin{array}{l}\text { Kemenko } \\
\text { PMK }\end{array}$ & $\begin{array}{l}\text { Psychology } \\
\text { Department } \\
\text { of Udayana } \\
\text { University }\end{array}$ & $\begin{array}{l}\text { BPBD } \\
\text { Lombok } \\
\text { Barat }\end{array}$ & $\begin{array}{l}\text { HIMPSI } \\
\text { NTB }\end{array}$ & $\begin{array}{l}\text { Pemdes } \\
\text { Kekait \& } \\
\text { Karang } \\
\text { Taruna } \\
\end{array}$ & $\begin{array}{l}\text { Pesantren } \\
\text { At-Tahzib }\end{array}$ & UNRAM & $\begin{array}{l}\text { UIN } \\
\text { Mataram }\end{array}$ \\
\hline $\begin{array}{l}\text { Aims in } \\
\text { the } \\
\text { project }\end{array}$ & $\begin{array}{l}\text { Develop and } \\
\text { improve } \\
\text { Sentuhan } \\
\text { Ibu }^{\mathrm{TM}} \text { as a } \\
\text { part of } \\
\text { company's } \\
\text { CSR }\end{array}$ & $\begin{array}{l}\text { Expand } \\
\text { collaboration } \\
\text { and scope of } \\
\text { organisation } \\
\text { program }\end{array}$ & $\begin{array}{l}\text { Monitoring } \\
\text { projects that } \\
\text { are in line } \\
\text { with the } \\
\text { institution's } \\
\text { vision }\end{array}$ & $\begin{array}{l}\text { Improve and } \\
\text { implement } \\
\text { mental } \\
\text { health } \\
\text { support } \\
\text { method }\end{array}$ & $\begin{array}{l}\text { Monitoring } \\
\text { projects } \\
\text { that are in } \\
\text { line with } \\
\text { the } \\
\text { institution's } \\
\text { vision }\end{array}$ & $\begin{array}{l}\text { Improve } \\
\text { and } \\
\text { impleme } \\
\text { nt mental } \\
\text { health } \\
\text { support } \\
\text { method }\end{array}$ & $\begin{array}{l}\text { Improve } \\
\text { the } \\
\text { mothers' } \\
\text { and } \\
\text { children' } \\
\text { s mental } \\
\text { health } \\
\text { status }\end{array}$ & $\begin{array}{l}\text { Improve } \\
\text { the } \\
\text { mothers' } \\
\text { and } \\
\text { children's } \\
\text { mental } \\
\text { health } \\
\text { status }\end{array}$ & $\begin{array}{l}\text { Students are } \\
\text { able to } \\
\text { achieve } \\
\text { hands on } \\
\text { experience } \\
\text { with } \\
\text { community } \\
\text { while } \\
\text { implementing } \\
\text { the learned } \\
\text { concept }\end{array}$ & $\begin{array}{l}\text { Students are } \\
\text { able to } \\
\text { achieve } \\
\text { hands on } \\
\text { experience } \\
\text { with } \\
\text { community } \\
\text { while } \\
\text { implementing } \\
\text { the learned } \\
\text { concept }\end{array}$ \\
\hline $\begin{array}{l}\text { Status } \\
\text { in the } \\
\text { project }\end{array}$ & $\begin{array}{l}\text { Coordinator } \\
\text { in the global } \\
\text { project }\end{array}$ & $\begin{array}{l}\text { Project } \\
\text { manager in } \\
\text { the local } \\
\text { project }\end{array}$ & $\begin{array}{l}\text { Project } \\
\text { Supervisor }\end{array}$ & $\begin{array}{l}\text { Research/ } \\
\text { development }\end{array}$ & $\begin{array}{l}\text { Local } \\
\text { Supervisor }\end{array}$ & $\begin{array}{l}\text { Research } \\
/ \\
\text { develop } \\
\text { ment }\end{array}$ & $\begin{array}{l}\text { Local } \\
\text { Partner }\end{array}$ & $\begin{array}{l}\text { Local } \\
\text { Partner }\end{array}$ & $\begin{array}{l}\text { Research/ } \\
\text { development } \\
\text { assistance }\end{array}$ & $\begin{array}{l}\text { Research/ } \\
\text { development } \\
\text { assistance }\end{array}$ \\
\hline $\begin{array}{l}\text { Activity } \\
\text { in the } \\
\text { project }\end{array}$ & $\begin{array}{l}\text { Supervise } \\
\text { local project } \\
\text { and help } \\
\text { project } \\
\text { management } \\
\text { by } \\
\text { providing } \\
\text { fund }\end{array}$ & $\begin{array}{l}\text { Planning and } \\
\text { coordinating } \\
\text { actors } \\
\text { involved }\end{array}$ & $\begin{array}{l}\text { Supervise } \\
\text { local project } \\
\text { and help } \\
\text { project } \\
\text { management } \\
\text { by providing } \\
\text { recommendati } \\
\text { ons }\end{array}$ & $\begin{array}{l}\text { Test, } \\
\text { implement } \\
\text { and evaluate } \\
\text { the } \\
\text { interventions }\end{array}$ & $\begin{array}{l}\text { Supervise } \\
\text { local } \\
\text { project and } \\
\text { help project } \\
\text { manageme } \\
\text { nt by } \\
\text { providing } \\
\text { recommend } \\
\text { ations }\end{array}$ & $\begin{array}{l}\text { Assist in } \\
\text { Test, } \\
\text { impleme } \\
\text { nt and } \\
\text { evaluate } \\
\text { the } \\
\text { intervent } \\
\text { ions }\end{array}$ & $\begin{array}{l}\text { Participa } \\
\text { te in the } \\
\text { project } \\
\text { as the } \\
\text { target } \\
\text { Provide } \\
\text { technical } \\
\text { assistanc } \\
\text { e on the } \\
\text { run of } \\
\text { the } \\
\text { project }\end{array}$ & $\begin{array}{l}\text { Provide } \\
\text { technical } \\
\text { assistance } \\
\text { on the run } \\
\text { of the } \\
\text { project }\end{array}$ & $\begin{array}{l}\text { Assist in } \\
\text { Test, } \\
\text { implement } \\
\text { and evaluate } \\
\text { the } \\
\text { interventions }\end{array}$ & $\begin{array}{l}\text { Assist in } \\
\text { Test, } \\
\text { implement } \\
\text { and evaluate } \\
\text { the } \\
\text { interventions }\end{array}$ \\
\hline Poles & $\begin{array}{l}\text { Financial } \\
\text { Pole }\end{array}$ & $\begin{array}{l}\text { Collaborating } \\
\text { Center } \\
\text { Institution }\end{array}$ & $\begin{array}{l}\text { General } \\
\text { Development } \\
\text { Pole }\end{array}$ & $\begin{array}{l}\text { Scientific } \\
\text { Pole }\end{array}$ & $\begin{array}{l}\text { Technical } \\
\text { Developme } \\
\text { nt Pole }\end{array}$ & $\begin{array}{l}\text { Scientifi } \\
\text { c Pole }\end{array}$ & $\begin{array}{l}\text { Target } \\
\text { Commun } \\
\text { ity }\end{array}$ & $\begin{array}{l}\text { Technical } \\
\text { Assistance } \\
\text { Pole }\end{array}$ & $\begin{array}{l}\text { Scientific } \\
\text { Pole }\end{array}$ & $\begin{array}{l}\text { Scientific } \\
\text { Pole }\end{array}$ \\
\hline
\end{tabular}

Our findings indicated that collaboration was best delivered when all parties involved had similar visions and considering other parties' needs and goals. The academics are Udayana OHCC, Psychology Department of Udayana University, Mataram University and Islamic University of Mataram, while the business actor is PT. Beiersdorf Indonesia (NIVEA). In this case, academics and business ensure the implementation of the program, both ensuring quality and financial security. Udayana $\mathrm{OHCC}$, which was responsible for the program planning and coordinating all the involved actors, aimed to expand collaboration and scope of organisation program. This aim was in line to One Health's value; coordination, collaboration and communication. The other academic actors are Psychology Department of Udayana University, HIMPSI Mataram, Mataram University and Islamic University of Mataram. These actors played role as the scientific pole, in which Udayana University as our main partner aimed to improve and implement mental health support method. Mataram University, HIMPSI Mataram and Islamic University of Mataram acted as supporting partners and aimed to enable their students to achieve hands on experience with community while implement the learned concept. Throughout the project, these partners were responsible for 
running the test, implement and evaluate the interventions. Another main actor in this project is PT Beiersdorf Indonesia (NIVEA) as the business pole that was responsible for funding the project through Corporate Social Responsibility (CSR) Scheme. Besides develop and improve Sentuhan $\mathrm{Ibu}^{\mathrm{TM}}$ as a part of the company's CSR, they were also in charge of supervising the project and help project management by providing fund. PT Beiersdorf Indonesia (NIVEA) also provides technical and conceptual assistance to ensure the program to be able to run well.

As the party that has the authority, the government plays an essential role in communicating the program to the community. This project supervised by Coordinating Ministry for Human Development and Cultural Affairs from the beginning until the closing of the program. Locally, we collaborated with Badan Penanggulangan Bencana Daerah, West Lombok, and the Kekait Village local government. These actors were responsible to monitor the project and make sure that it is in line with institution's vision. Likewise, the community also plays a crucial role in the sustainability of the program. In a religious and traditional community like this, we realized the program could gain success because we involved Karang Taruna, Village Cadres and Pesantren as our partners. The community appeared to be eager to join the program if they knew that the local community organisations endorsed the program.

Challenges, such as miscommunication and the existence of special norms applicable in the local area can be overcome by the existence of a clear division of duties in the collaboration agreement between all parties. Realizing that there is no dominant party is also one of the important things to hold the community for the sake of program sustainability.

\section{CONCLUSION}

We discovered that collaboration is more connected when the whole stakeholders acted as their aim-based role. These connections moved from compromising to collaborating by the time agreement signed and fluidly changed throughout the project. Issues such as sustainability and participation can be handled by involving the community from the preparation until follow up phase. All research studies have limitations, and this study is no exception. Our study has a limitation regarding the scope and period of the program. On this case, this study only analysed one case in a short period of time (less than 12 months from planning to evaluation). Although this is able to assess the roles of each actor in stimulating a type of collaboration, other analysis can still be done using this case such as collaboration dynamic, and its development factors.

\section{ACKNOWLEDGMENT}

This project funded by PT. Beiersdorf Indonesia (NIVEA) under the Sentuhan Ibu ${ }^{\mathrm{TM}}$ CSR Program. We thank the support and supervising from the Coordinating Ministry for Human Development and Cultural Affairs, Indonesia One Health University Network (INDOHUN) and Udayana University Rectorate throughout the project, as well as other mention partners in this project.

\section{REFERENCES}

[1] Beringer C, Jonas D, Kock A. Behavior of internal stakeholders in project portfolio management and its impact on success. International Journal of Project Management. 2013;31(6):830-46.

[2] Littau P, Jujagiri NJ, Adlbrecht G. 25 Years of Stakeholder Theory in Project Management Literature (1984-2009). 2010;41(4):17-29.

[3] Achterkamp MC, Vos JFJIJoPM. Investigating the use of the stakeholder notion in project management literature, a metaanalysis. 2008;26(7):749-57.

[4] Bäckstrand KJEE. Multi-stakeholder partnerships for sustainable development: rethinking legitimacy, accountability and effectiveness. 2006;16(5):290-306.

[5] Hubacek K, Prell C, Reed M, Boys D, Bonn A, Dean CJTiJoBs, et al. Using stakeholder and social network analysis to support participatory processes. 2006;2(3):249-52.

[6] Prell C, Hubacek K, Reed MJS, Resources N. Stakeholder analysis and social network analysis in natural resource management. 2009;22(6):501-18.

[7] Klijn E-H, Teisman GRJPm, Management. Institutional and strategic barriers to public-private partnership: An analysis of Dutch cases. 2003;23(3):137-46.

[8] Haas PMJGep. Addressing the global governance deficit. 2004;4(4):1-15.

[9] Wilson EJ, Bunn MD, Savage GTJIMM. Anatomy of a social partnership: A stakeholder perspective. 2010;39(1):76-90.

[10] Missonier S, Loufrani-Fedida SJIJoPM. Stakeholder analysis and engagement in projects: From stakeholder relational perspective to stakeholder relational ontology. 2014;32(7):110822.

[11] Bitzer V, Glasbergen P, Leroy PJGN. Partnerships of a feather flock together? An analysis of the emergence of networks of partnerships in the global cocoa sector. 2012;12(3):355-74. 